Review

\title{
How will climate change affect oil palm fungal diseases?
}

\author{
R.R.M. Paterson ${ }^{\mathrm{a}, *}$, M. Sariah ${ }^{\mathrm{b}}$, N. Lima ${ }^{\mathrm{a}}$ \\ ${ }^{a}$ IBB - Institute for Biotechnology and Bioengineering, Centre of Biological Engineering, Universidade do Minho, 4710-057 Braga, Portugal \\ ${ }^{\mathrm{b}}$ Institute of Tropical Agriculture, Universiti Putra Malaysia, 43400 UPM Serdang, Selangor, Malaysia
}

\section{A R T I C L E I N F O}

Article history:

Received 6 July 2012

Received in revised form

27 December 2012

Accepted 29 December 2012

\section{Keywords:}

Oil palm

Climate change

Ganoderma

Fusarium

\begin{abstract}
A B S T R A C T
Palm oil is a very important commodity. It is added to numerous products and is a biofuel. However, oil palms (OP) are subjected to fungal diseases of which Fusarium wilt and Ganoderma rots are the most important. Considerations of how climate change (CC) affects tropical economic plants are limited and for $\mathrm{OP}$ are even fewer. The margin for adapting to higher temperatures and changing humidity is reduced in tropical OP. Land will become increasingly unsuitable for growing OP and the plants will become stressed allowing ingress of fungal diseases. New land will be increasingly suitable where the environmental conditions are less severe than in the tropics. Novel diseases may threaten the crop. Finally, the effect of the major consequences of CC on OP fungal diseases is considered herein with a view to establishing key hypotheses.
\end{abstract}

(C) 2013 Elsevier Ltd. All rights reserved.

\section{Introduction}

Palm oil is very important. The product is utilized worldwide and included in ca. 30\% of foods, pharmaceuticals and cosmetics (Paterson et al., 2009). In addition, palm oil biodiesel is contributing to the fuel requirements of Malaysia (Lim and Lee, 2012).

Oil palm (OP) is the primary source of vegetable oil and fat making it a crop of rapidly-increasing utilization. Biofuel markets will increase demand further, generating high yields at low costs where OP revenue accounts for $5.1 \%$ of the gross national income of Malaysia (Ewers et al., 2011). Malaysia has export earnings from products of $\$ 18$ billion in 2009, when cultivation increased from $5.4 \times 10^{4}$ ha in 1960 to $4.7 \times 10^{6}$ in 2009 . Crude palm oil production increased from $9.4 \times 10^{4}$ tonnes to $1.8 \times 10^{7}$ in 2009 and the exports of OP products increased from $2.17 \times 10^{7}$ tonnes in 2008, to $2.24 \times 10^{7}$ in 2009 (Chong, 2011). Worldwide production rose from 2.2 million tonnes of palm oil in 1972 to 21 million in 2000 (Paterson et al., 2009). Finally, OP monoculture has replaced 22,242 ha of Ecuador's coastal Chocó rainforest since 1998 (Hazlewood, 2012).

Many people are living in hunger and malnutrition (Tirado et al., 2010a) and it is necessary to manage food resources such as OP carefully. However, climate change (CC) will affect the supply and safety of food: Concentrations of methane, carbon dioxide, nitrous oxide and chlorofluorocarbons in the atmosphere are increasing,

\footnotetext{
* Corresponding author. Tel.: +351 253604 423; fax: +351 253678986 .

E-mail address: russell.paterson@deb.umino.pt (R.R.M. Paterson).
}

resulting in environmental warming, greater precipitation, and/or drought, leading Sant'Ana (2010) to state that CC is of unrivalled importance. Valid predictions can be made based on existing information (Paterson and Lima, 2010), hence it is important to consider some of the fundamental properties of the OP as these will be relevant to effects from changing weather.

\section{Oil palm}

The native range of $\mathrm{OP}$ is disputed: Elaeis guineensis occurs in the tropical rainforest belt of West Africa between $10^{\circ} \mathrm{N}$ and $10^{\circ} \mathrm{S}$ and is native to a $200-300 \mathrm{~km}$ coastal belt from approximately $15^{\circ} \mathrm{N}$ to $15^{\circ} \mathrm{S}$. Important oil-palm-producing countries include Indonesia, Malaysia, Nigeria, Democratic Republic of the Congo, the Ivory Coast, Brazil, Colombia, Costa Rica, and Ecuador (Corley and Tinker, 2003). The natural environment is where rainfall is $1780-2280 \mathrm{~mm}$ per annum, with a 2-4 month dry period, although the palm grows in areas with annual rainfall of $640 \mathrm{~mm}$ or $4200 \mathrm{~mm}$ (Duke, 1983). Mean maximum and minimum temperatures are 30-32 and 21$24{ }^{\circ} \mathrm{C}$ : growth may cease below $15^{\circ} \mathrm{C}$. E. guineensis is affected by high temperatures, with photochemical efficiency reduced above $35^{\circ} \mathrm{C}$. The plant grows on a wide range of tropical soils within $\mathrm{pH}$ 4-8 if sufficiently moist (Duke, 1983) and needs open areas, as the plant cannot compete with faster-growing trees; it does not grow under continuous flooding. However, the tree tolerates fluctuating water tables with periods of standing water and so may cope with flooding episodes from CC. Natural habitats are swamps, riverbanks and other areas too wet for dicotyledonous trees of the tropical rain forest. 
The equatorial belt offers suitable cultivation conditions, where mean annual rainfall deficits do not exceed 600-650 mm annually. Highest yields are achieved where rain is well distributed throughout the year with an optimum of $150 \mathrm{~mm}$ monthly: OP grows less well currently at higher altitudes (above 500-600 m) and latitudes (above $10^{\circ}$ ). Productivity and growth are severely reduced (Duke, 1983; CABI) at below $20{ }^{\circ} \mathrm{C}$ for prolonged periods, although regions currently experiencing this climate may become suitable (Table 1 ).

\section{Fungal diseases of oil palm}

Oil palm plants are subjected to various fungal diseases of which Fusarium wilt (Ploetz, 2006; Flood, 2006) and Ganoderma rots (Paterson, 2007) are the most important.

\subsection{Fusarium}

The most destructive disease of OP in Africa is Fusarium vascular wilt caused by Fusarium oxysporum f. sp. elaeidis. However, Fusarium incarnatum, Fusarium solani, and a Fusarium spp. were isolated from Indonesian OP with spear rot (Suwandi Akino and Kondo, 2012) and the relation to the wilt needs determining which is endemic in several African countries. Outbreaks in South America may have resulted from inter-continental seed movements: awareness in Malaysia must be maintained (Cooper, 2011). Two disease syndromes are seen: acute wilt with death in a few weeks and chronic wilt where the palm remains alive for years with stunting. F. oxysporum f. sp. elaeidis is a soil borne fungus and the perennial nature of the crop ensures that the disease is difficult to control. However, it is absent in South East Asia because of adequate quarantine measures (Ploetz, 2006; Flood, 2006), although it may occur if production is moved because of CC (Table 1; Fig. 1).

The disease was first described in the Democratic Republic of Congo and reported in Côte d'Ivoire, Nigeria, Ghana, Cameroon, and Congo: Localized outbreaks occurred in Brazil and Ecuador. Stunting is from decreased petiole and leaf lamina sizes caused by reduced cell division. The younger, stunted leaves were associated with prolonged, mild water stress which could occur with CC, and the older non-stunted leaves were permanently water stressed which grew before the pathogen became established. The fungus grows directly to the vascular elements from roots, although the host can limit spread, producing gums, gels, and tyloses that impede transpiration. In susceptible OP, tyloses, gels and antifungal metabolites are produced more slowly allowing the fungus to colonize further, leading to more vascular occlusion and external symptoms. Nonpathogenic isolates from OP plantation soils and roots of healthy palms (from Malaysia and from Zaire (Flood, 2006) may provide a source of pathogens in response to changing weather.

Spear rots are the phytosanitary problem of real importance in tropical America which may involve fungi, although it is surprising that those involved remain unknown (Chinchilla, 2008) until recently (Suwandi Akino and Kondo, 2012), where the fungal origin of the disease was determined in Indonesia. Common spear rot (CSR), or crown disease, causes considerable losses in OP plantings which was first reported in Indonesia in the 1920s. Fourteen different fungal taxa were isolated, including F. incarnatum, F. solani, and the Fusarium spp. mentioned above. However, F. incarnatum and some Fusarium spp. were also isolated frequently from healthy leaf tissue. Importantly, F. sacchari infected OP leaves containing wounds and caused a symptom of extensive rotting similar to that found in the field; other Fusarium species were weakly virulent on palms with succulent growth (Other fungi are associated (see section 3.3).

\subsection{Ganoderma rots}

This OP disease has been described by Paterson (2007) and Paterson et al. (2009). Interestingly, OP was free of reports of serious diseases until World War II, hence the increase in disease may be related to CC. Indeed there have been severe to devastating outbreaks as the crop area has expanded and the seriousness of the disease has increased dramatically over a short period. Ganoderma is becoming prevalent in younger palms and seedlings which again may be related to preternatural changes in weather, as in the past the rots were of old, replanted areas of Asia.

Paterson et al. (2008) mentions that lignin degradation is less efficient at $37^{\circ} \mathrm{C}$ compared to $25^{\circ} \mathrm{C}$ and global warming may cause lignin degradation to be less efficient, making the rots less prevalent in the next 50 years (Paterson, 2007) (Fig. 2). The fungus infected 1-2 years after planting with increases observed in 4-5 year old palms where infection in inland soil in Malaysia and Indonesia on seven year old plantations was low: Incidence was high in OP grown inland. Ganoderma infections occur over periods of years, which are much longer than the time scales of other fungal plant pathogens (e.g. F. oxysporum) (Paterson, 2007). If Fusarium wilt takes hold in Southeast Asia, it could become dominant over Ganoderma rots and more work is required to understand better the enzymatic processes involved in these diseases.

A paucity of information exists on the physiology of growth of Ganoderma spp. involved in OP disease. Soil temperatures frequently rise above $40{ }^{\circ} \mathrm{C}$ and reach $45^{\circ} \mathrm{C}$, whereas in shade they never exceeded $32{ }^{\circ} \mathrm{C}$ (Rees et al., 2007) and G. boninense is probably inhibited in exposed soil. Death at $45^{\circ} \mathrm{C}$ will limit Ganoderma disease, however, new strains may be selected (Fig. 2).

\subsection{Other fungi}

The fungal disease of fatal yellowing or lethal bud rot of OP is caused by Thielaviopsis paradoxa which attacks non-lignified tissue, providing a useful contrast to Ganoderma. The teleomorphic stage, Ceratocystis paradoxa causes the disease dry basal rot, although this appears similar to basal stem rot, which can also be described erroneously as a dry rot (Paterson, 2007; Paterson et al., 2009).

Table 1

Changes in disease scenarios because of transitions from current conditions through intermediate conditions and then to the final conditions from climate change.

\begin{tabular}{|c|c|c|c|}
\hline Scenario & Current climate 2012 & Intermediate climate & Final climate 2062 \\
\hline 1 & $\begin{array}{l}\text { High temperature, poor rainfall }=\text { disease } \\
\text { containable }\end{array}$ & $\begin{array}{l}\text { Conditions become increasingly poor. } \\
\text { Temperature }=33^{\circ} \mathrm{C} \text {. Disease increases }\end{array}$ & $\begin{array}{l}\text { Too severe for OP. No disease as } \\
\text { no OP. Temperature } \geq 33^{\circ} \mathrm{C}\end{array}$ \\
\hline 2 & $\begin{array}{l}\text { Benign conditions for oil palm. Temperature } \\
28-30^{\circ} \mathrm{C} \text {. Disease present but not problematic }\end{array}$ & $\begin{array}{l}\text { Generally conditions are satisfactory } \\
\text { and diseases containable }\end{array}$ & $\begin{array}{l}\text { Conditions become increasingly poor. } \\
\text { Temperature }=33^{\circ} \mathrm{C} \text {. Disease increases }\end{array}$ \\
\hline 3 & Sub tropical climate but inappropriate for OP. & Land is prepared for oil palm. & $\begin{array}{l}\text { Benign climate conditions for oil palm. } \\
\text { Planted in new land without disease history. } \\
\text { Parasite lost scenario may play a role and low } \\
\text { disease level achievable. }\end{array}$ \\
\hline
\end{tabular}



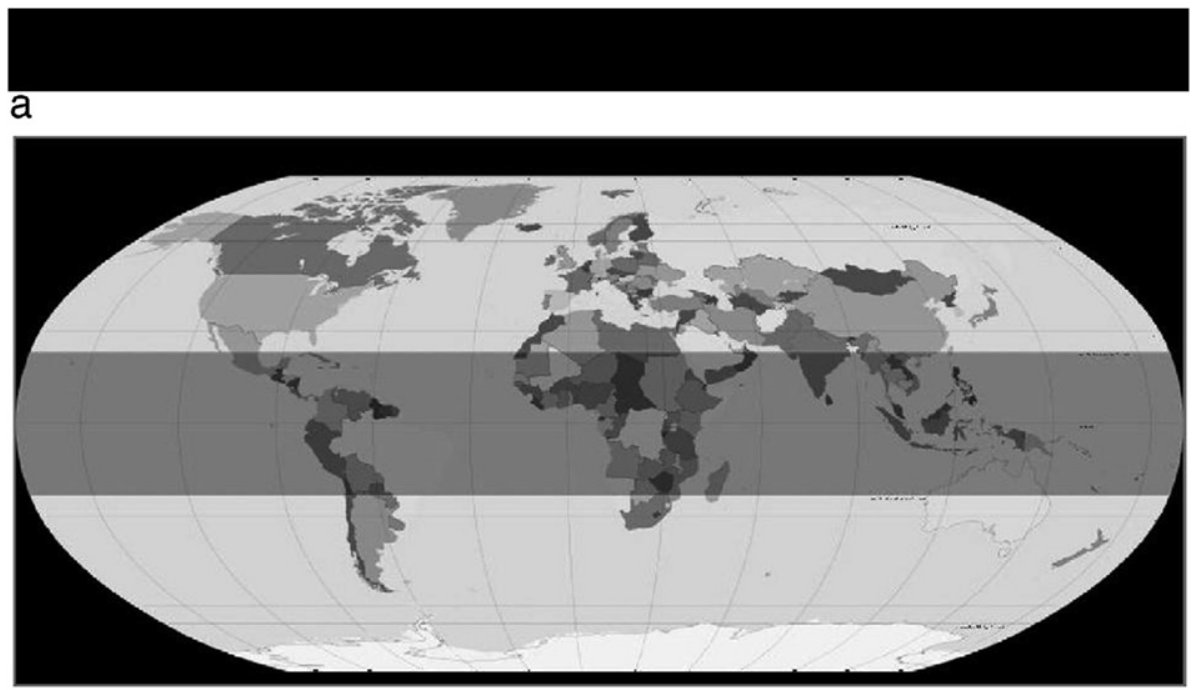

b

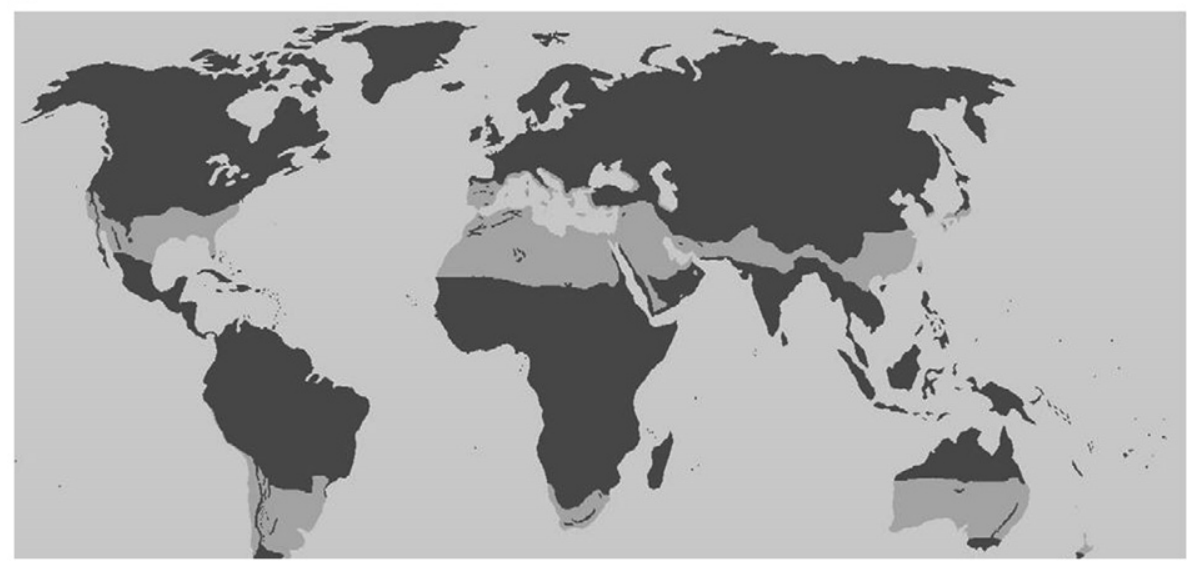

Fig. 1. Tropical (a) and sub-tropical (b) areas in the world. Tropical regions are anticipated to become subtropical in climate change scenarios (Paterson and Lima, 2011).

Spear rots are important in tropical America. CSR was first reported in Indonesia in the 1920s especially in OP plantings. Fourteen different fungal taxa were isolated which, apart from the fusaria mentioned previously, include $C$. paradoxa isolated frequently from diseased leaf tissue, and also implicated in dry basal rot (see section 3.1). Pestalotiopsis microspora and Curvularia affinis were also isolated frequently from healthy leaf tissue. Importantly, C. paradoxa was not isolated from healthy leaf tissue and Koch's postulate experiments demonstrated that $C$. paradoxa infected wounded OP leaves causing a symptom of extensive rotting similar to that found in the field. Other fungi were weakly-virulent on palms with succulent growth (Suwandi Akino and Kondo, 2012). The most important fungal disease in Colombia is bud rot by Phytophthora palmivora destroying several plantations since 1964 and which has recently destroyed more than (a) 30,000 ha in the South West Colombia and (b) 10,000 in the Central Zone which may be related to CC. The infection is present in all stages from nursery to the end of the production cycle (Martinez et al., 2011).

Finally, accurate diagnostic methods are required (Paterson (2007): A novel application involving ergosterol analysis was published which shows promise in determining Ganoderma disease (Mohd Aswad et al., 2011). Better methods are required for the diagnosis of Fusarium disease (see Flood, 2006): For example, can existing methods differentiate between $F$. oxysporum f. sp. elaeidis and the fusaria involved in crown rot?

\section{Climate change predictions}

We will consider predominantly temperature and humidity changes as these (a) are the most significant CC factors (Ingram, 1999) and (b) have been considered most thoroughly for fungi (Paterson and Lima, 2010; 2011). However, concentrations of ozone, sulphur dioxide and carbon dioxide will also affect OP disease requiring consideration when data become available. A warmer planet is "virtually certain" and warm spells or heat waves are "very likely" (IPCC, 2007) with profound impacts on agriculture. Furthermore, increases in losses of soil minerals, variation in their bioavailability and alterations in soil microorganism ecosystems are all discussed in the IPCC report. Temperature will rise by approximately $4{ }^{\circ} \mathrm{C}$ in 100 years which will affect fungal diseases: some may become less prevalent as the temperatures become too high in tropical regions (Table 1 ).

The lack of information on CC and tropical crops is profound and, for example, OP is only mentioned once in Ghini et al. (2011). Many data indicate that plant epidemics are influenced climatically and changing temperature and rainfall (in particular) threaten food security (Miraglia et al., 2009; van der Fels-Klerx et al., 2009; Tirado et al., 2010b), which will have a negative impact especially in developing (or newly industrialized) countries, where commercial OP are grown (Chakraborty et al., 2000; Anderson et al., 2004; Stern, 2007; van der Fels-Klerx et al., 2009). 


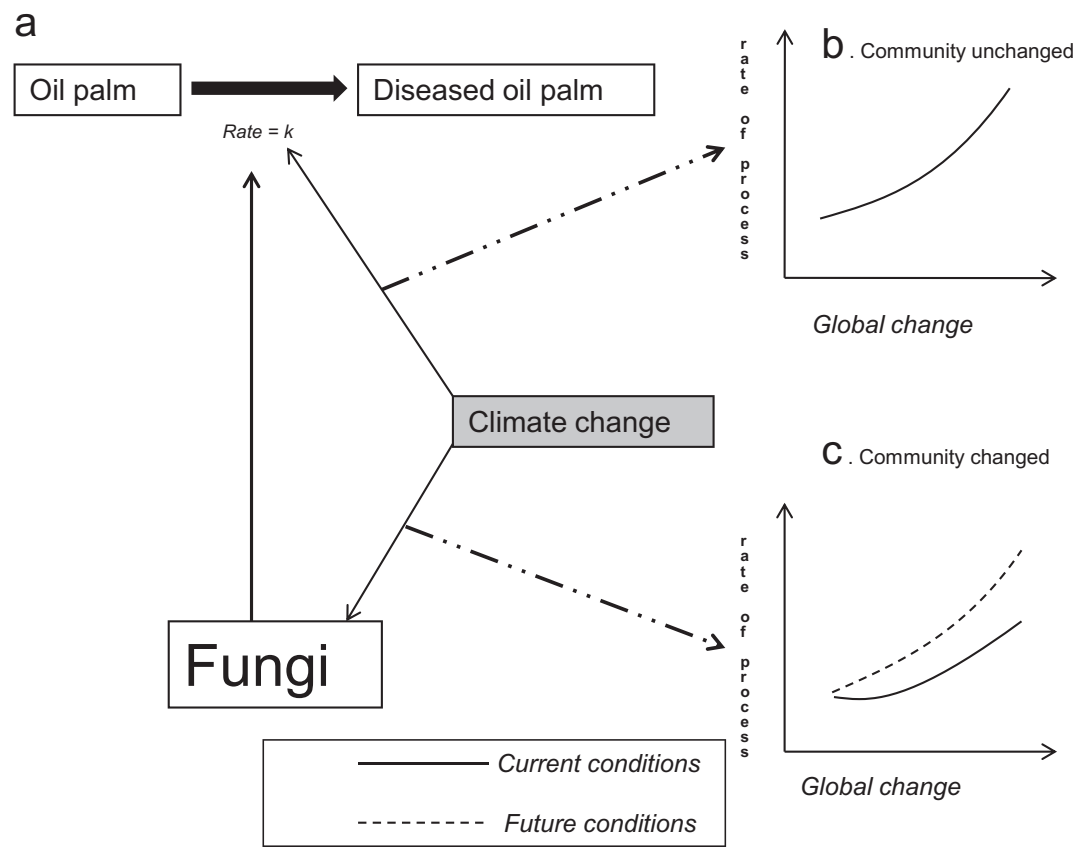

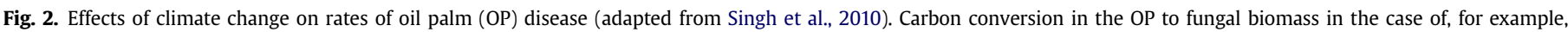

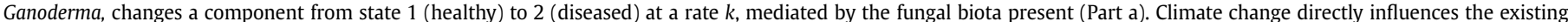

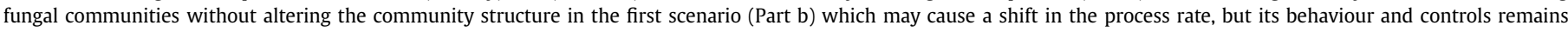

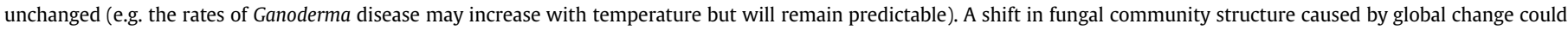
also alter the fundamental control mechanism of the process as in the second scenario (Part c).

\section{Climate change and tropical agricultural production}

Effects of CC on agriculture include (a) reduced yields in warmer regions as a result of heat stress, (b) damage to crops, (c) soil erosion, (d) inability to cultivate land caused by heavy precipitation events and (e) land degradation resulting from increasing drought. The reduction in agricultural production will be more severe in tropical regions, where there is a shortage of food production. However, multifactorial studies, such as free air $\mathrm{CO}_{2}$ enrichment are difficult to control in tropical climates (Ghini et al., 2011), making the work of Shahabuddin et al. (2011) even more relevant.

Climate Change will cause agricultural production systems to decline drastically particularly in Sub-Saharan Africa and South Asia suggesting that they will decrease for palm oil. The novel weather will lead to more intense and longer droughts in the tropics and sub-tropics, with the numbers of people affected being largest in the mega-deltas of Asia and Africa. Coastal areas will be at greatest risk due to increased flooding. General crop productivity is projected to decrease with small local temperature increases in tropical regions (Easterling et al., 2007). Sea-level rise is projected to extend areas of salination of groundwater and estuaries, resulting in a decrease of coastal freshwater availability for agriculture systems including OP. Finally, small islands are especially vulnerable to the effects of CC, sea-level rise and extreme events, relevant particularly to countries such as Indonesia (Tirado et al., 2010a).

Models in IPCC (2007) suggest that moderate local increases in temperature $\left(1-3{ }^{\circ} \mathrm{C}\right)$, with associated $\mathrm{CO}_{2}$ increase and rainfall changes, can have large effects in the tropics, where even slight warming $\left(1-2{ }^{\circ} \mathrm{C}\right)$ reduces yield. Further warming (above $1-3{ }^{\circ} \mathrm{C}$ ) will have increasingly negative impacts on global food production (Easterling et al., 2007). For example, droughts, floods and higher temperatures impact crop susceptibility to fungal attack reducing the stability of food and stocks which applies to fungal diseases of OP.

\section{Climate change effects on oil palms}

There are few directly-related reports on the effect of CC on OP growth. Legros et al. (2009) indicate how flowering of OP is controlled by photoperiod response, even near the equator, in a study which discusses climate variability. Furthermore, OP will be affected by $\mathrm{CC}$ in a study that correlates atmospheric $\mathrm{CO}_{2}$ with mean temperature (Shahabuddin et al., 2011). Palms were cultivated in Open Top Chambers (OTC) under ambient and elevated $\mathrm{CO}_{2}$ levels (750 ppm) which enhanced biomass by approximately $22 \%$ and mean leaf area by $36 \%$. Net photosynthesis was increased by $14 \%$. It was suggested that the OP cultivation could reduce anthropogenic $\mathrm{CO}_{2}$ and lead to better yields (Shahabuddin et al., 2011) which is an optimistic way of considering predicted CC. It is interesting that the $\mathrm{CO}_{2}$ affects OP so significantly, considering it does not affect fungi to a great extent (Paterson and Lima, 2011), although more work is required.

\section{Effects in oil palm regions}

Southeast Asia will be very vulnerable to $\mathrm{CC}$ and may become unsuitable for OP cultivation. There is a pole ward tendency for crops to migrate allowing more northerly (or southerly) countries to produce palm oil. Paterson and Lima (2011) indicate how currently tropical crops will be grown increasingly in currently subtropical regions (Fig. 1). For example, maize is a tropical crop (e.g. Paterson and Lima, 2011) and the suitability of land for its growth will change with CC (Paterson and Lima, 2012). Crops will be affected by these alterations in three manners: For example, specific regions for maize growth will (a) remain or become suitable, or (b) become unsuitable (Shaw and Osborne, 2011; Paterson and Lima, 2012). Similarly, there are three basic scenarios that are likely to occur for OP: Land will (a) remain suitable, although crops will experience more stress from higher temperatures and/or 
drought; (b) become unsuitable for OP and will experience a period of increasing stress leading to fungal disease; and (c) become suitable for OP providing an opportunity to grow disease-free palms (Paterson and Lima, 2011) (see section 11).

Furthermore, climatic factors in Malaysia have been changing rapidly, affecting agricultural productivity (Alam et al., 2012). Forests, which can be converted to OP, are under threat from the effects of CC. Ewers et al. (2011) examined the effects in Sabah, Borneo where some of the area has undergone, or is undergoing, conversion to OP and forest rehabilitation projects have also been instituted (Hector et al., 2011). Agriculture is becoming increasingly vulnerable to risk and uncertainty because of CC. Crop yield will be reduced and it may cause drought in many areas of Malaysia so that cultivation of OP will be impossible (Alam et al., 2012). Projections indicate that maximum monthly precipitation will increase up to 51\% in Pahang, Kelantan and Terengganu, and the minimum precipitation will decrease by $32-61 \%$ for Peninsular Malaysia. However, annual rainfall will increase by $10 \%$ in Kelantan, Pahang, Terengganu, and the North-West Coast and decrease by 5\% in Johor and Selangor causing risk and uncertainty. The average temperature in the rice growing areas in Malaysia is $26^{\circ} \mathrm{C}$ which overlap with OP areas, leading to decrease yields in rice and a similar situation occurring with OP. The Integrated Agricultural Development Area, Northwest Selangor, Malaysia covers an area of 100,000 ha of which 55,000 ha are marked for cultivation of OP. Alam et al. (2012) indicate that the yearly total rainfall is increasing and the monthly variation is too high.

Unfortunately, there is a lack of information on CC for Asia in the IPCC report where much OP is grown (IPCC, 2007), although the situation may be somewhat similar to Latin America, in that change will occur in already hot regions in some cases, with rain forest implications, and in countries which could be considered as developing (or newly industrialized). Predictions relating to tropical countries are relevant: Fresh water availability will decrease by 2050 and coastal areas are at greatest risk from flooding from the sea and rivers. Fewer crops/yields will occur from changing weather in currently hot regions (Table 1) and the crops produced will be of lower quality due to the stress effects of the change, and this will apply to OP. There will be greater damage from flooding, and more ingress of fungi via the damaged crop.

A significant increase in temperature, and decreased soil water (IPCC, 2007) is predicted in Latin America in general. The tropical forest will become savanna grassland and semi arid land crops will be replaced by arid vegetation. Significantly, tropical species extinction will occur, which is relevant particularly to OP growth and is likely to result in considerable loss and increased disease: Crop productivity will decrease leading to adverse food security situations.

In currently hot climates (IPCC, 2007), the temperatures reached will be extremely high and may lead to the extinction of fungi. These temperatures will be too high for the current fungal disease of OP and the OP (Table 1). However, cool areas will change to hot or tropical and so may become suitable. As part of the general "movement of crops to the Poles" (Pritchard, 2011), the conditions for production of OP will become optimal in currently subtropical regions such as the Southern United States of America. The current sub-tropical countries consist of the major developed countries, e.g. parts of the USA (Fig. 1), which may be able to manage increased OP disease even more effectively. Malaysia, Indonesia and countries in Latin America, may find that it is difficult to grow OP, whereas Southern China, Northern India, Pakistan, Afghanistan, the Middle East Southern Europe and North Africa will increasingly be capable (Fig. 1). Similarly, parts of the USA, Argentina, South Africa and Australia may also become suitable.

\section{Fungal disease of plants and climate change}

It can be problematic to distinguish the long-term effects of CC on disease epidemics in agricultural crops from short-term effects of seasonal changes and agronomic practices. Changes will occur in the type, amount and relative importance of pathogens and diseases (including non-fungal diseases). Importantly, host resistance may be overcome more rapidly due to accelerated pathogen evolution (Fig. 2) from increased fecundity at high $\mathrm{CO}_{2}$ and/or enhanced UV-B radiation. Shaw et al. (2008) demonstrated how the limitations of models and experiments can be overcome by making use of a long-term (1844-2003) data sets on the occurrence of two key worldwide pathogens (Phaeosphaeria nodorum and Mycosphaerella graminicola) of wheat. Wheat herbarium specimens were used for PCR analysis which provided a unique way of characterizing changes in pathogen prevalence over time in relation to emissions of $\mathrm{CO}_{2}$ and $\mathrm{SO}_{2}$. However, similar studies may not be possible with OP as suitable herbarium probably do not exist.

Slightly elevated $\mathrm{CO}_{2}$ concentrations and interactions with temperature and water availability may stimulate growth of some fungal species, especially under water stress (Magan et al., 2011), although the information relating to this is slight. The concentration would increase from 0.03 to $0.08 \%$ in the atmosphere if the predicted $\mathrm{CO}_{2}$ increase from $\mathrm{CC}$ is maintained for the next 100 years (IPCC, 2007). Unfortunately, there is currently a lack of information on the effect of these low concentrations on fungi, hence more work is required. The increase in $\mathrm{CO}_{2}$ is predicted to increase the metabolism of crops providing higher yields and this applies to OP as mentioned. Increased stomata closure will be associated inevitably with lower latent heat loss, thereby increasing leaf temperatures and affecting how and which fungi infect the plant (DaMatta et al., 2010; Paterson and Lima, 2010).

Modelling studies provide increasingly realistic scenarios for the influence on some plant diseases of changes in climate. This situation does not exist for OP diseases. A consideration of what is known and can be extrapolated from, existing information on other systems is of considerable value, such as information on Leptosphaeria maculans, Plasmopara viticola, and the distribution of forest pathogens in France (Paterson and Lima, 2010).

Global warming will not only act on pathosystems already present in certain regions, but will favour the emergence of new diseases, because the (i) distributional range, temporal activity and community structure of pathogens will be modified (e.g. Shaw et al., 2008), and (ii) phenology and conditions of the hosts will be altered (e.g. Jeger et al., 2007) (Fig. 2). One scenario could be of some OP diseases being unable to survive in the new environment and, indeed, the evidence that CC can profoundly influence hostpathogen dynamics is growing (e.g. Haines et al., 2006).

Plants grown in elevated $\mathrm{CO}_{2}$ were more infected with leaf blast, than plants grown in ambient $\mathrm{CO}_{2}$. The most probable impact of elevated $\mathrm{CO}_{2}$ on plant disease epidemics would be from changes in the host physiology and morphology (Chakraborty et al., 1998) rather than a more infective pathogen (e.g. better penetration) and this may be the case with OP fungi in a general manner (Shahabuddin et al., 2011). The ability of OP disease fungi to mutate and respond to opportunities arising from change is a key factor in considering the potential impact of CC (Fig. 2). Finally, CC may affect not only the geographical range and abundance of vectors, but also the interaction between a pathogen and a vector (e.g. the pathogen may be transmitted by new vectors).

\section{Tropical crops disease and climate change}

The effects of CC on diseases of tropical crops virtually have been ignored. There has been limited work on the effects on pathologies 
of eucalyptus, sugarcane, coffee, cassava, banana, pineapple, citrus, cashew, coconut and papaya (Ghini et al., 2011) and some general points can still be made.

The limited information available is based on modelling studies; little empirical knowledge exists for the development of adaptation strategies (Ghini et al., 2011). Long-term datasets are rare in relation to tropical and plantation crop diseases, which are a prerequisite for finding fingerprints of inter-annual climatic variation on plant diseases (Jeger and Pautasso, 2008). However, increased disease in OP has been recorded since World War II as mentioned above which could be from CC.

Multifactor studies of CC effects have not been attempting for tropical and plantation crop diseases. Experimental studies of the long-term effects of increased $\mathrm{CO}_{2}$ and $\mathrm{O}_{3}$ concentrations on tropical and plantation crops in more realistic field settings have not yet been carried out on a comprehensive scale, although the first such attempt was made by Shahabuddin et al. (2011). The general rule that high concentration of atmospheric $\mathrm{CO}_{2}$ results in higher yield and plant development is not always applicable. Ghini et al. (2011) states that new OTC designs and environmental control systems are necessary to address the requirements of tropical plant pathosystems.

Much of the literature deals with modelling approaches to determine how the distribution of a particular tropical disease may change (Ghini et al., 2008). Deutsch et al. (2008) observed that warming in the tropics is likely to have the most deleterious consequences because tropical insects are sensitive to temperature change and are currently living very close to their optimal temperature. The lack of vectors will make disease less likely, although diseases such as Ganoderma rots of OP are not dependent on spread by insects (Rees et al., 2007). It is important to consider what is known about the diseases of other tropical crops when considering OP.

Elevated atmospheric $\mathrm{CO}_{2}$ concentration on the latent period of coffee leaf rust was evaluated (Ghini et al., 2011). The average latent period was ca. 36 days at 400 p.p.m., reduced to 21, 21 and 19 days at 500, 700 and 900 p.p.m. $\mathrm{CO}_{2}$, respectively. Furthermore, Booth et al. (2000) performed a risk analysis for the occurrence of Cylindrocladium quinqueseptatum on eucalyptus: The authors used climate-change scenarios to suggest that areas in mainland South East Asia may become vulnerable to $C$. quinqueseptatum over the next 50 years which is of particular relevance to OP disease. The potential impact on eucalyptus rust disease (Puccinia psidii) indicated that there will be a reduction of the favourable area in Brazil for the disease. Furthermore, Black Sigatoka (Mycosphaerella fijiensis) is the most damaging disease of banana and Ghini et al. (2007) studied the potential impact of CC by using IPCC scenarios. Maps projected a reduction in the favourable area to the disease in Brazil resulting from a reduction in relative humidity to levels below $70 \%$. Extensive areas will remain favourable to this disease. Finally, De Jesus et al. (2008) used the IPCC scenarios and predicted that favourable areas for the development of the disease will decrease.

Panama disease (F. oxysporum f. sp. cubense) is another important disease which is prevalent in most banana growing regions. The Fusarium OP disease is $F$. oxysporum f. sp. elaeidis and so there may be some value in a comparison with banana. It has been suggested that the importance of Panama disease will increase with CC by rising temperatures and periods of drought altering the banana physiology, causing stress, and increasing the aggressiveness of $F$. oxysporum f. sp. cubense in susceptible cultivars, in contrast to Black Sigatoka (Ghini et al., 2007). Similarly, the pineapple disease, caused by Fusarium subglutinans f. sp. ananas, may be reduced in significance by increased temperatures (Matos et al., 2000). These could occur with OP although again the effects on the palm and the specific pathogen require consideration.
Of more relevance to OP is coconut palm (Cocos nucifera), although the diseases are different. CC is predicted to reduce the importance of black leaf spot (Camarotella torrendiella and Camarotella acrocomiae), phytomonas wilt (Phytomonas sp.), blight and leaf spots (Bipolaris incurvata) and heart rot (Phytophthora spp.). However, the importance of leaf blight (Botryosphaeria cocogena) of coconut palm in Brazil (Ghini et al., 2011) will be at least be maintained although more published work is required. Again, these assessments are based on observed effects of reduced precipitation and increased temperature.

\section{Climate change and oil palm disease}

Climate change will raise uncertainty in the production of OP as global warming will increase the range and severity of plant diseases of worldwide importance within the next 20 years (Garrett et al., 2006; Huang et al., 2006; Miraglia et al., 2009), although CC may actually decrease the severity of epidemics in some cases (Chakraborty et al., 1998). More crops/greater yields will occur in currently cooler regions (e.g. sub-tropical) and fewer crops/yields will occur in currently hotter regions (e.g. tropical) (IPCC, 2007; Paterson and Lima, 2011) and this will apply to OP. Also, it is important to consider whether disease will increase proportionately. OP will grow in currently cool climates as temperature increases in these regions and an increase in the total amount of disease will tend to occur, simply because there are more crops (Table 1) (equivalent to scenario 1 in Paterson and Lima (2011).

In addition, fewer crops/yields will occur from CC in some currently hot regions. This may lead to a decrease in the total amount of OP disease simply because there will be fewer OP (equivalent to scenario 2 in Paterson and Lima (2011). Consequently, there will be a proportionate reduction in the need to analyse OP in these areas for disease, as they will be fewer. It is possible that the OP produced will give lower yields due to the stress effects of CC and so they may contain more disease per area of land under OP (Table 1). Increased crop stress from heavy precipitation will occur with lower crop yields and these will have lowered resistance to fungal invasion and consequently, increases in disease. There is a trend towards lower overall disease if the amount of OP grown is reduced and vice versa. Precipitation will increase at high latitudes, whilst decreases are likely in most subtropical land from intensification of the global hydrological cycle. Extremes of daily precipitation will very likely increase in Northern Europe, Southern and Eastern Asia, Australia, and New Zealand, and in many other regions. Summer drying of midcontinental areas risks drought and half of the plant species may be at threatened (IPCC, 2007; Miraglia et al., 2009). This will affect OP. However, it is unlikely that OP will be produced in Northern European regions within the time frame, as temperatures and conditions will remain sub-optimal (Table 1); these regions will become temperate from cold. This is not the case for Southern Europe which could become more tropical, allowing the growth of OP (Fig. 1).

Damage to crops (e.g. OP), soil erosion, and inability to cultivate land are all predicted in the IPCC (2007) report which will lead to greater fungal ingress and more disease caused by fungi that are already present. Hence, as Fusarium is controlled tightly in Malaysia this will result in Ganoderma remaining the problem. Furthermore, soil erosion allows leaching of nutrients away from the plant, decreasing resistance to fungal infection, and resulting in more disease. Drought stress will be important particularly in developing countries: Marginal land where stress tolerant sorghum was grown has been replaced with maize especially in Africa (IPCC, 2007; Miraglia et al., 2009) and this changing of crop may occur with OP.

Many of those factors by which CC affects OP disease will interact with each other in ways that may not be fully understood (Fig. 2). Alterations in plantation practice and land use may occur 
concurrently with anthropogenic changes such as deforestation, economic change and social change. The emergence of disease covers evolution of new microbes, expansion in geographic range, increase in incidence, change in pathways or pathology (Fig. 2) and infection in new host species or populations (Olival and Daszak, 2005). Hence different OP disease fungi may evolve and rates of infection will change (see Paterson and Lima, 2011).

Temperature, humidity, and sunlight affect the survival of pathogens able to live independently of the host. Noor et al. (2011) found that the soil temperature associated with an OP was $27.25^{\circ} \mathrm{C}$ and that leaf temperature was remarkably similar at $27.69{ }^{\circ} \mathrm{C}$ : Soil moisture content was as high as $26.52 \%$. The temperatures are all favourable for fungal diseases such as Ganoderma. Rees et al. (2007) determined that soil temperatures in sunlight frequently rose above $40{ }^{\circ} \mathrm{C}$ and reached $45{ }^{\circ} \mathrm{C}$, whereas in shade they never exceeded $32^{\circ} \mathrm{C}$. The authors surmised that $\mathrm{G}$. boninense is inhibited in exposed soil. Hence, more measurement of temperatures is required, as are assessments of the physiology of growth of OP fungi.

An important indirect factor is that the feeding rate of many arthropod vectors increases at higher temperatures, thus increasing exposure of crops to OP disease. The main effect of CC on mean temperature is by warmer night-time temperatures which is important for many insect vectors that fly and feed at that time (Paterson and Lima, 2010): OP disease fungi can be spread by insect vectors making this factor relevant. Emissions of $\mathrm{CO}_{2}$ and $\mathrm{SO}_{2}$ are affecting plant-pathogen interactions in natural and agricultural ecosystems worldwide from CC and pollution (Garrett et al., 2006), and will be relevant to OP disease.

\section{Parasites lost}

The "Parasites lost" phenomenon will occur as crops (e.g. OP) are moved to new growing regions. Such crops often thrive, with increases in body mass and spread, from the loss of their associated pests. The introduced plant may experience the "enemy release" phenomenon resulting in reduced natural enemy attack. For example, 473 plant species naturalised to the United States from Europe had on average, $84 \%$ fewer fungi infecting each plant species (Mitchell and Power, 2003).

\section{Fungi, biosynthesis rates and climate models}

Climate Change will alter rates of OP disease (Singh et al., 2010) and the rate can change according to the response of fungal communities (Fig. 2), although the consequences are not known if climate changes beyond the limits. If the structure of the fungal community changes in such a way that the function alters, a discontinuity in the response may occur and the response could move to a different path (Fig. 2, part c). Understanding these potential threshold effects remain key challenges in plant diseases including disease of OP.

\section{Conclusions}

Oil Palm will suffer more diseases in the current growing areas because of greater stress imposed by the novel climates. Fusarium wilts may become more prevalent in SE Asia especially if quarantines are breached. Some areas may no longer be capable of growing the plant and so disease will be irrelevant. On the other hand, new areas will become available where diseases could be reduced. However, the emergence of new or unusual diseases needs consideration. Basic information is required on the physiology of growth and enzyme production of the existing fungal pathogens to enable accurate predictions. More information is required on host-pathogen interactions and the effect of microbemicrobe interactions on the OP diseases. For example, the effects of CC on experimental biological control microorganisms (e.g. Trichoderma) and biofertilizers (e.g. mycorrhiza) tested on OP, require consideration, but are beyond the scope of the present review. There is a wide range of fungi involved in OP disease about which little is known and more work is needed: Better diagnostic methods are also required.

Most of the global warming during the next 30 years will be due to emissions that have already occurred. Over the longer term, the degree and pace of warming mainly depend on current and near future emissions (Stern, 2007). In recent years, adaptation has gained prominence as an important response measure especially in vulnerable countries. It has become clear that some impacts are now unavoidable in the short to medium term. Different countries have applied various approaches and techniques to adapt with climatic vulnerabilities and Malaysia is developing its adaptation policy for averting the adverse climatic impacts (Alam et al., 2012). CC brings new challenges to palm oil production which must be anticipated well in advance of major problems occurring.

\section{References}

Alam, M.M., Siwar, C., Molla, R.I., Talib, B., bin Toriman, M.E., 2012. Paddy farmers' adaptation practices to climatic vulnerabilities in Malaysia. Mitig. Adapt. Strat. Glob. Change 17, 415-423.

Anderson, P.K., Cunningham, A.A., Patel, N.G., Morales, F.J., Epstein, P.R., Daszak, P., 2004. Emerging infectious diseases of plants: pathogen pollution, climate change and agrotechnology drivers. Trends Ecol. Evolut 19, 535-544.

Booth, T.H., Jovanovic, T., Old, K.M., Dudzinski, M.J., 2000. Climatic mapping to identify high-risk areas for Cylindrocladium quinqueseptatum leaf blight on eucalypts in mainland South East Asia and around the world. Environ. Pollut. 108, 365-372.

CABI Invasive Species Compendium http://www.cabi.org/isc/?compid=5\&dsid= 20295\&loadmodule $=$ datasheet $\&$ page $=481 \&$ site $=144(25 / 05 / 12$.$) .$

Chakraborty, S., Murray, G.M., Magarey, P.A., Yonow, T., O’Brien, R.G., Croft, B.J., et al., 1998. Potential impact of climate change on plant diseases of economic significance to Australia. Australas. Plant. Pathol. 27, 15-35.

Chakraborty, S., Tiedemann, A.V., Teng, P.S., 2000. Climate change: potential impact on plant diseases. Environ. Pollut. 108, 317-326.

Chinchilla, C., 2008. The Many Faces of Spear Rots in OP: the Need for an Integrated Management Approach. ASD Oil Palm Papers 32, pp. 1-25.

Chong, K.P., 2011. Oil Palm and Ganoderma: Direction on Future Research. VDM Verlag Dr, Muller GmbH \& Co, KG, Saarbrucken, Germany.

Cooper, R.M., 2011. Fusarium wilt of oil palm: a continuing threat to South East Asian plantations. Planter 87, 409-418.

Corley, R.H.V., Tinker, P.B., 2003. The Oil Palm. Blackwell Publishing, Oxford.

DaMatta, F.M., Grandis, A., Arenque, B.C., Buckeridge, M.S., 2010. Impacts of climate changes on crop physiology and food quality. Fd. Res. Int. 43, 1814-1823.

De Jesus Jr., W.C., Valadares Jr., R., Cecílio, R.A., Moraes, W.B., Do Vale, F.X.R., Alves, F.R., Paul, P.A., 2008. Worldwide geographical distribution of Black Sigatoka for banana: predictions based on climate change models. Sci. Agricola 65, 40-53.

Deutsch, C.A., Tewksbury, J.J., Huey, R.B., Sheldon, K.S., Ghalambor, C.K., Haak, D.C., Martin, P.R., 2008. Impacts of climate warming on terrestrial ectotherms across latitude. Proc. Natl. Acad. Sci. U.S.A. 105, 6668-6672.

Duke, J.A., 1983. Elaeis guineensis Jacq. Purdue University, USA. http://www.hort. purdue.edu/newcrop/duke_energy/Elaeis guineensis.html (25/05/12.).

Easterling, W.E., Aggarwal, P.K., Batima, P., Brander, K.M., Erda, L., Howden, S.M., et al., 2007. Food, fibre and forest products. In: Parry, M.L., Canziani, O.F., Palutikof, J.P., van der Linden, P.J., Hanson, C.E. (Eds.), Climate Change 2007: Impacts, Adaptation, and Vulnerability, Contribution of Working Group II to the Fourth Assessment Report of the Intergovernmental Panel on Climate Change. Cambridge University Press., New York, pp. 273-314.

Ewers, R.M., Didham, R.K., Fahrig, L., Ferraz, G., Hector, A., Holt, R.D., 2011. A largescale forest fragmentation experiment: the stability of altered forest ecosystems project. Phil. Trans. R. Soc. (B) 366, 3292-3302.

Flood, J., 2006. A review of Fusarium wilt of oil palm caused by Fusarium oxysporum f. sp. elaeidis. Phytopathology 96, 660-662.

Garrett, K.A., Dendy, S.P., Frank, E.E., Rouse, M.N., Travers, S.E., 2006. Climate change effects on plant disease: genomes to ecosystems. Annu. Rev. Phytopathol. 44, 489-509.

Ghini, R., Hamada, E., Bettiol, W., 2008. Climate change and plant diseases. Sci. Agricola 65, 98-107.

Ghini, R., Hamada, E., Gonçalves, R.R.V., Gasparotto, L., Pereira, J.C.R., 2007. Risk analysis of climatic change on Black Sigatoka on banana in Brazil (Análise de risco das mudanças climáticas globais sobre a Sigatoka-negra da bananeira no Brasil). Fitopatol. Bras 32, 197-204. 
Ghini, R., Bettiol, W., Hamada, E., 2011. Diseases in tropical and plantation crops as affected by climate changes: current knowledge and perspectives. Plant. Pathol. $60,122-132$.

Haines, A., Kovats, R.S., Campbell-Lendrum, D., Corvalan, C., 2006. Climate change and human health: impacts, vulnerability and public health. Publ. Health 120, 585-596.

Hazlewood, J.A., 2012. $\mathrm{CO}_{2}$ lonialism and the "unintended consequences" of commoditizing climate change: geographies of hope amid a sea of OP in the northwest Ecuadorian Pacific region. J. Sustainable For. 31, 120-153.

Hector, A., Fowler, D., Nussbaum, R., Weilenmann, M., Walsh, R.P.D., 2011. The future of South East Asian rainforests in a changing landscape and climate. Phil. Trans. R. Soc. (B) 366, 3165-3167.

Huang Y, Evans, N., Li, Z Eckert, M. Chèvre, A, Renard, M., Fitt, B.D.L, 2006. Temperature and leaf wetness duration affect phenotypic expression of Rlm6mediated resistance to Leptosphaeria maculans in Brassica napus. New Phytol. $170,129-141$.

Ingram, D.S., 1999. British society for plant pathology presidential address 1998 : biodiversity, plant pathogens and conservation. Plant Pathol. 48, 433-442.

IPCC, 2007. Intergovernmental Panel on Climate Change Report. In: Climate Change 2007: Synthesis Report.

Jeger, M.J., Pautasso, M., Holdenrieder, O., Shaw, M.W., 2007. Modeling disease spread and control in networks: implications for plant sciences. New Phytol. 174, 279-297.

Jeger, M.J., Pautasso, M., 2008. Plant disease and global change - the importance of long-term data sets. New Phytol. 177, 8-11.

Legros, S., Mialet-Serra, I., Caliman, J., Siregar, F.A., Clément-Vidal, A., Dingkuhn, M. 2009. Phenology and growth adjustments of oil palm (Elaeis guineensis) to photoperiod and climate variability. Ann. Bot. 104, 1171-1182.

Lim, S., Lee, K.T., 2012. Implementation of biofuels in Malaysian transportation sector towards sustainable development: a case study of international cooperation between Malaysia and Japan. Renew. Sust. Energ. Rev. 16, 1790-1800.

Magan, N., Medina, A., Aldred, D., 2011. Possible climate-change effects on mycotoxin contamination of food crops pre- and postharvest. Plant Pathol 60, 150-163.

Martinez, G., Arango, M., Torres, G., Sarria, G., Velez, D., Rodriguez, J., Mestizo, Y., Aya, H., Norena, C., Varon, F., Drenth, A., Guest, D., 2011. Advances in the research of the two most important diseases on oil palm in Colombia: bud rot and lethal wilt. In: Proceedings of the PIPOC 2011 International Palm Oil Congress, 15-17 Nov, Kuala Lumpur, Malaysia, pp. 473-480.

Matos, A.P., Cabral, J.R.S., Sanches, N.F., Caldas, R.C., 2000. Effect of temperature and rainfall on the incidence of Fusarium subglutinans on pineapple fruits. Acta Hort 529, 265-272.

Miraglia, M., Marvin, H.J.P., Kleter, G.A., Battilani, P., Brera, C., Coni, E., et al., 2009. Climate change and food safety: an emerging issue with special focus on Europe. Food Chem. Toxicol. 47, 1009-1021.

Mitchell, C.E., Power, A.O., 2003. Release of invasive plants from fungal and viral pathogens. Nature 421, 625-627.

Mohd Aswad, A.W., Sariah, M., Paterson, R.R.M., Zainal Abidin, M.A., Lima, N., 2011 Ergosterol analyses of oil palm seedlings and plants infected with Ganoderma. Crop Prot. 30, 1438-1442.

Noor, M.R.M., Rosli, S.K., Muhammad, Z., Harun, M.H., Hashim, A.T., 2011. Microclimate and physiological status of an immature oil palm. In: Proceedings of the
PIPOC 2011 International Palm Oil Congress, 15-17 Nov, Kuala Lumpur, Malaysia, pp. 340-342.

Olival, K.J., Daszak, P., 2005. The ecology of emerging neurotrophic viruses J. Neurovirol. 11, 441-446.

Paterson, R.R.M., 2007. Ganoderma disease of oil palm-A white rot perspective necessary for integrated control. Crop Prot. 26, 1369-1376.

Paterson, R.R.M., Lima, N., 2010. How will climate change affect mycotoxins in food? Fd. Res. Int. 43, 1902-1914.

Paterson, R.R.M., Lima, N., 2011. Further mycotoxin effects from climate change. Fd. Res. Int. 44, 2555-2566.

Paterson, R.R.M., Lima, N., 2012. Climate Change, Fumonisins and Animal Feed. In Binder, E.M. (Ed.), NutriEconomics: Balancing Global Nutrition and Productivity, Biomin World Nutrition Forum. 10-13th October 2012, Singapore. pp. 241-247. ISBN: 978-0-9573721-2-2.

Paterson, R.R.M., Moen, S., Lima, N., 2009. The feasibility of producing oil palm with altered lignin content to control Ganoderma disease. J. Phytopathol.157, 649-656.

Paterson, R.R.M., Meon, S., Zainal Abidin, M.A., Lima, N., 2008. Prospects for inhibition of lignin degrading enzymes to control Ganoderma white rot of oil palm. Curr. Enzym. Inhib. 4, 172-179.

Ploetz, R.C., 2006. Fusarium-induced diseases of tropical, perennial crops. Phytopathology 96, 648-652.

Pritchard, S.G., 2011. Soil organisms and global climate change. Plant Pathol. 60 82-99.

Rees, R.W., Flood, J., Hasan, Y., Cooper, R.M., 2007. Effects of inoculum potential, shading and soil temperature on root infection of oil palm seedlings by the basal stem rot pathogen Ganoderma boninense. Plant Pathol. 56, 862-870.

Sant'Ana, A.S., 2010. Special issue on climate change and food science. Fd. Res. Int 43, 1727-1728.

Shahabuddin, N.A., Harun, M.H., Noor, M.R.M., Yunos, M.H.M., 2011. Growth and photosynthesis of oil palm under elevated carbon dioxide. In: Proceedings of the PIPOC 2011 International Palm Oil Congress 15-17 Nov, Kuala Lumpur, Malaysia, pp. 322-326

Shaw, M.W., Osborne, T.M., 2011. Geographic distribution of plant pathogens in response to climate change. Plant Pathol. 60, 31-43.

Shaw, M.W., Bearchell, S.J., Fitt, B.D.L., Fraaije, B.A., 2008. Long-term relationships between environment and abundance in wheat of Phaeosphaeria nodorum and Mycosphaerella graminicola. New Phytol. 177, 229-238.

Singh, B.K., Bardgett, R.D., Smith, P., Reay, D.S., 2010. Microorganisms and climate change: terrestrial feedbacks and mitigation options. Nat. Rev. Microbiol. 8 779-790.

Stern, N., 2007. The Economics of Climate Change: the Stern Review. Cambridge University Press, Cambridge, UK.

Suwandi Akino, S., Kondo, N., 2012. Common spear rot of oil palm in Indonesia. Plant. Dis. 96, 537-543.

Tirado, M.C., Cohen, M.J., Aberman, N., Meerman, J., Thompson, B., 2010a Addressing the challenges of climate change and biofuel production for food and nutrition security. Fd. Res. Int. 43, 1729-1744.

Tirado, M.C., Clarke, R., Jaykus, L.A., McQuatters-Gollop, A., Frank, J.M., 2010b. Climate change and food safety: a review. Fd. Res. Int. 43, 1745-1765.

van der Fels-Klerx, H.J., Kandhai, M.C., Brynestad, S., Dreyer, M., Börjesson, T. Martins, H.M., et al., 2009. Development of a European system for identification of emerging mycotoxins in wheat supply chains. World Mycotoxin J. 2, 119-127. 